\title{
Structural performance assessment of reinforced concrete flat slab-edge column connections under the effects of outward eccentricity
}

\section{Avaliação do desempenho estrutural de ligações de borda em lajes lisas de concreto armado sob os efeitos da excentricidade externa}
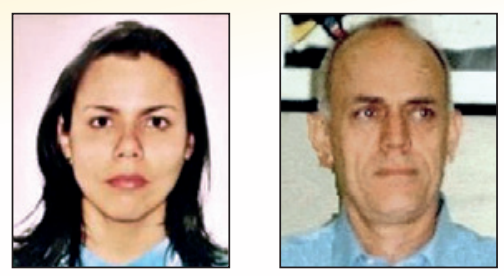

N. G. B. ALBUQUERQUE a
niveagabriela@hotmail.com

G. S. S. A. MELO

melog@unb.br

\begin{abstract}
Although several advantages - either constructive or architectural - are assigned to flat slabs, the continuity between consecutive spans in multifloor buildings may turn slab-column connections into a critical region, due to the limited contact between both elements. When transferring moments caused by horizontal and/or vertical eccentric loads are present, these effects are even more pronounced on external panels. Specific studies on the effects of outward eccentricities are still rather scarce, although it is recognized that the codes, in general, are concerned with eventually meeting all potential cases, seeking to improve safety structural performance. Some current recommendations are based on considerable extrapolations, whose theory was originally developed for cases of asymmetric loading at internal connections and need to be consolidated with specific test data. Thus, to investigate the structural behaviour of slabs-edge columns connections, four specimens were tested, reproducing a $2,350 \mathrm{~mm} \times 1,700 \mathrm{~mm}$ portion of a $180 \mathrm{~mm}$ thick reinforced concrete slab adjacent to a $300 \mathrm{~mm} \times 300 \mathrm{~mm}$ cross section squared edge column, with a projection at the base for the imposition of eccentricities. The position of the support under the column has determined the eccentricity, defining in physical terms the interaction between bending moment and shear force, as follows: $300 \mathrm{~mm}$ (inward), centred (reference) and $300 \mathrm{~mm}$ and $400 \mathrm{~mm}$ (outward). Experimental results allowed to comparatively assess the performance of the specimens relating the strain measurements in steel and concrete, vertical displacements, rotations, failure mode and ultimate loads of the slabs. Results indicate that the influence of transferring moments on failure modes is much more pronounced than the shear action in the case of edge connections subjected to outward eccentricities.
\end{abstract}

Keywords: flat slabs, edge column, eccentricity, punching shear, reinforced concrete.

\section{Resumo}

Embora diversas vantagens - construtivas e/ou arquitetônicas - Ihe sejam atribuídas, a continuidade entre vãos consecutivos de lajes lisas adotadas em projetos multipavimentos faz da ligação laje-pilar uma região crítica, dada a reduzida seção de contato entre os dois elementos. Com a transmissão de momentos devido à adição de carregamentos horizontais e/ou verticais excêntricos, esses efeitos são ainda mais pronunciados em painéis externos. Estudos específicos sobre os efeitos de excentricidades externas ainda são bastante escassos, embora se reconheça a preocupação das normas, em geral, estarem aptas a atender eventualmente todos os potenciais casos conexos, visando um desempenho estrutural seguro. Para o caso de ligações de borda, algumas das recomendações existentes são baseadas em extrapolações bastante consideráveis, cuja teoria foi originalmente desenvolvida para os casos de carregamento assimétrico em ligações internas e precisam ser consolidadas com dados experimentais específicos. Assim, para investigar o comportamento estrutural das ligações entre a laje e o pilar de borda foram ensaiados quatro specimenos individuais que reproduziram uma porção de laje de $2.350 \times 1.700 \mathrm{~mm}$ de um pavimento de concreto armado com $180 \mathrm{~mm}$ de espessura em torno do pilar de borda quadrado de seção transversal $300 \mathrm{~mm} \times 300 \mathrm{~mm}$, dotado de uma projeção para imposição das excentricidades. A posição do apoio sob o pilar determinou a excentricidade em termos físicos, variável estudada que definiu a interação $M / V$, a saber: $300 \mathrm{~mm}$ (interna), centrada (referência) e $300 \mathrm{~mm}$ e $400 \mathrm{~mm}$ (externa). Os ensaios experimentais possibilitaram avaliar comparativamente o comportamento dos specimenos quanto às medições de deformações no aço e no concreto, deslocamentos verticais, rotações, modo de ruptura e cargas últimas das lajes. Os resultados indicam que a influência da transferência dos momentos nos modos de ruptura das lajes é muito mais pronunciada que ação do cisalhamento nos casos de ligações de borda submetidas a excentricidades externas.

Palavras-chave: lajes lisas, pilar de borda, excentricidade, punção, concreto armado.

Universidade de Brasília, Faculdade de Tecnologia, Departamento de Engenharia Civil e Ambiental, Campus Universitário Darcy Ribeiro, Brasília - DF, Brasil. 


\section{Introduction}

Reinforced concrete flat slabs structures have been established as a viable alternative to conventional system of solid slabs, beams and columns, emphasizing its functionality and its economy. Among their advantages is that the elimination or reduction of the number of beams implies reducing materials and labour related to formwork manufacturing and wall covering, as well as promoting greater agility in executing services such as: installation of reinforcing steel, placement and compaction of concrete and removal of formwork [1]. However, it is necessary to watch out for while implementing this system, especially because among some of topics they include the possibility of failure by punching at the slab-column connection. This failure type is fragile and occurs when shear becomes critical, so that the connection behaviour is important to know about. Another noteworthy aspect regarding punching failure is that when it occurs, there is a great possibility of progressive collapse to happen throughout the structure, if it is not able to absorb the extra forces due to load redistribution.

Many studies on this subject are needed since the main international codes have differences among themselves. Conducting experimental studies is crucial to understand punching-shear phenomenon, since it allows a comparison and its suitability to code's provisions aiming a safe and economic design. When it comes to edge column connections with transferring moment the amount of existing studies is greatly reduced, and when the bending moment is the result of an outward eccentricity, the references are scarce [2], [3].

In a real situation, transferring moment can occur, for example, in a structure under the effect of earthquakes. Another cause is the existence of horizontal forces induced by wind or even a situation in which the eccentricity is foreseen by project. Generally, there are two tests that simulate a moment transferred from column to slab: those resulting from horizontal forces on the stubs of a column and those whose eccentricity is imposed under the column support, as shown in Figure 1. The last option was adopted in this work as it was considered more appropriate to the available test setup and loading apparatus. Thus, these two possible cases of transferring moment about an axis parallel to the slab edge are exemplified, defining directions as inward or outward eccentricity depending on the column rotation (that is taken as inward when the column stub extended below the slab rotates toward the interior; and as outward when the column rotates in the opposite direction).

\section{Experimental program}

\subsection{Design of test specimens}

Punching tests here described were part of the work of Feliciano [4] and Albuquerque [5], which comprised a series containing four specimens reproducing the region of the slab around an edge column. An original and unpublished test setup was adopted regarding the definitions of boundary conditions used to perform tests of this nature; it comes, therefore, an appropriate measure, given its economic feasibility, simplicity in design, especially for representing the actual behaviour of a real structure.

The four specimens were simply supported in the largest dimension side (longitudinal direction or $\mathrm{x}$-axis) of the slab, using a roller under the column base and a continuous pin near the other end. Load was applied via two hydraulic actuators attached to load cells positioned directly above the distribution beams at the ends of the shortest dimension side (transverse direction or $y$-axis), through four steel plates equally positioned about the centre of the jacks, as shown in Figure 2. The position of the support under the column determined the eccentricity, and the column projection was

\section{Figure 1 - Behaviors generated by: (a) inward eccentricities; (b) outward eccentricities}
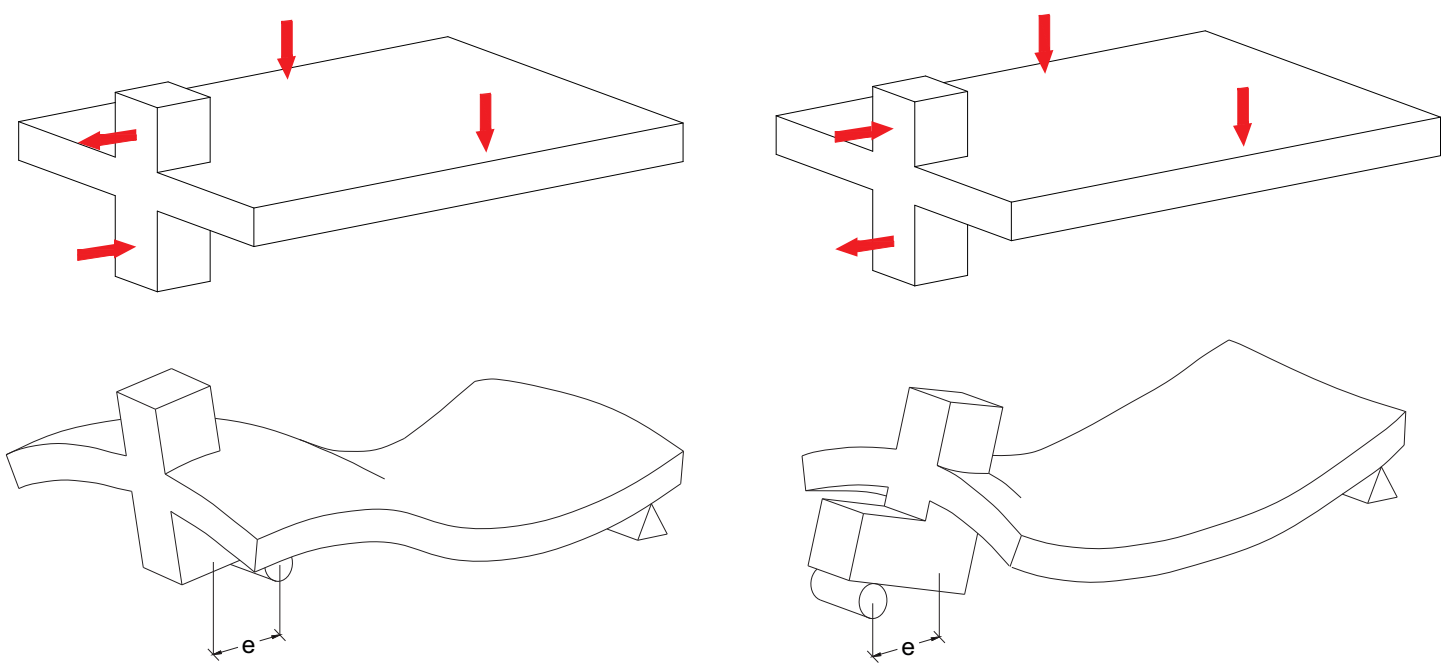

A 
conveniently orientated in accordance to the variable direction. Table 1 shows the eccentricity used for each specimen, considering outward eccentricity as positive.

\subsection{Construction of slab specimens}

\subsubsection{Geometry}

Specimens were constructed with overall dimensions of $1,700 \mathrm{~mm}$ by $2,350 \mathrm{~mm}$ and $180 \mathrm{~mm}$ thick slab, connected to a $300 \mathrm{~mm}$ by
$300 \mathrm{~mm}$ column of $830 \mathrm{~mm}$ height, which extended a projection of $350 \mathrm{~mm}$ for imposing the support eccentricity related to the column axis, being $300 \mathrm{~mm}$ height of from the base of the column. Dimensions were defined in order to adapt to the existing frame arrangement in the Structures Lab at University of Brasilia. The column projection was oriented toward exterior for slabs with centred or outward eccentricity; and it was oriented toward interior when eccentricity was inward. Figure 3 illustrates a representation of the loading and the boundary conditions for slabs where projections shall comply with either shown direction.

Figure 2 - Application of loads
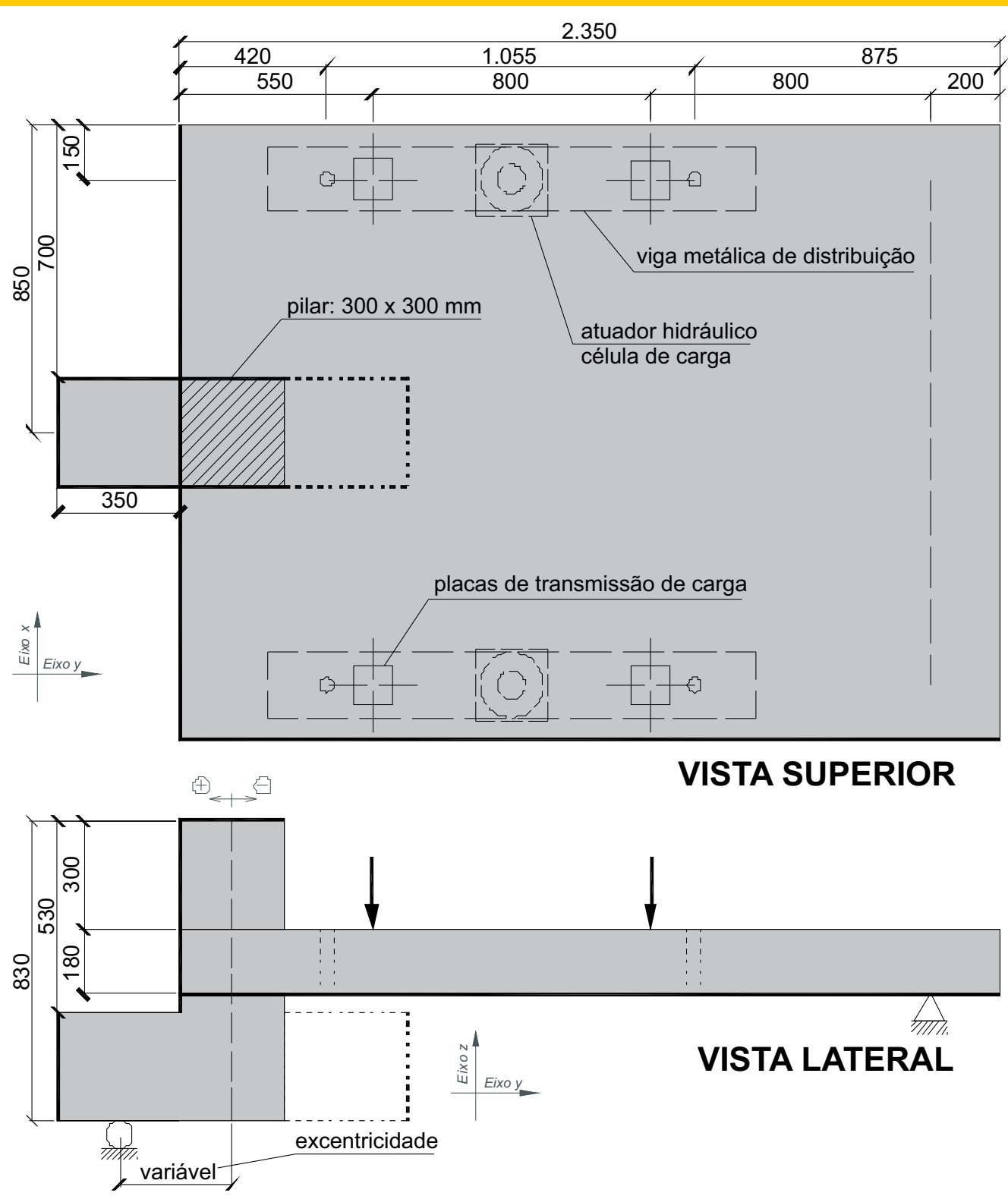

(Dimensions in $\mathrm{mm}$ ) 


\section{Table 1 - Eccentricities under column supports}

\begin{tabular}{|cc|}
\hline Specimens & $e(\mathrm{~mm})$ \\
\hline L1 & -300 (inward) \\
L2 & 0 (centred) \\
L3 & 300 (outward) \\
L4 & 400 (outward) \\
\hline
\end{tabular}

\subsubsection{Slab reinforcement}

The slabs were reinforced to bending in both directions. Reinforcement at the top consisted of 15 bars with a diameter of $12,5 \mathrm{~mm}$ arranged at a spacing of $100 \mathrm{~mm}$ in longitudinal direction, being folded as a hook at one extreme end (close to column edge) and 20 straight bars with a diameter of $16 \mathrm{~mm}$ arranged at a spacing of $100 \mathrm{~mm}$ in the transverse direction, attached to hooks at both ends. Reinforcement at the bottom consisted of 15 bars with a di- ameter of $16 \mathrm{~mm}$ arranged at a spacing of $100 \mathrm{~mm}$ the longitudinal direction, being folded as a hook at one extreme end (close to column edge) and 12 straight bars with a diameter of $16 \mathrm{~mm}$ arranged at a spacing of $200 \mathrm{~mm}$ in the transverse direction.

\subsubsection{Column reinforcement}

Vertical column reinforcement was provided by adding 8 bars with a diameter of $16 \mathrm{~mm}$ that composed four straight bars and four "corbel" anchoring bars. As column ties, confining stirrups with a diameter of $6,3 \mathrm{~mm}$ were used, being spaced at $100 \mathrm{~mm}$. Figure 4 schematically shows the distribution of the reinforcement in both column and slab.

\subsubsection{Construction sequence}

The specimens have been monolithically cast at the same day with ready mix concrete with a nominal compressive strength specified in $40 \mathrm{MPa}$. Brazilian West Central region crushed aggregate was used, such as sand and gravel. The maximum coarse aggregate size was $9.5 \mathrm{~mm}$. Workability test was carried out on concrete be-

\section{Table 2 - Ultimate loads and failure modes}

\begin{tabular}{|c|c|c|c|c|c|c|c|}
\hline Specimens & $e(\mathrm{~mm})$ & $\mathrm{f}_{\mathrm{c}}(\mathrm{MPa})$ & $f_{c t}(M P a)$ & $E_{c}(G P a)$ & $\mathrm{V}_{\mathrm{u}}(\mathrm{kN})$ & $P_{u}(k N)$ & Failure mode \\
\hline L1 & -300 & 46.8 & 3.4 & 29.3 & 308 & 437 & Punching* \\
\hline L2 & 0 & 44.7 & 3.0 & 27.5 & 315 & 525 & Punching \\
\hline L3 & 300 & 45.1 & 3.1 & 27.1 & 256 & 490 & Flexural \\
\hline L4 & 400 & 46.0 & 3.3 & 28.5 & 210 & 420 & Flexural \\
\hline
\end{tabular}

Figure 3 - Longitudinal view of the model

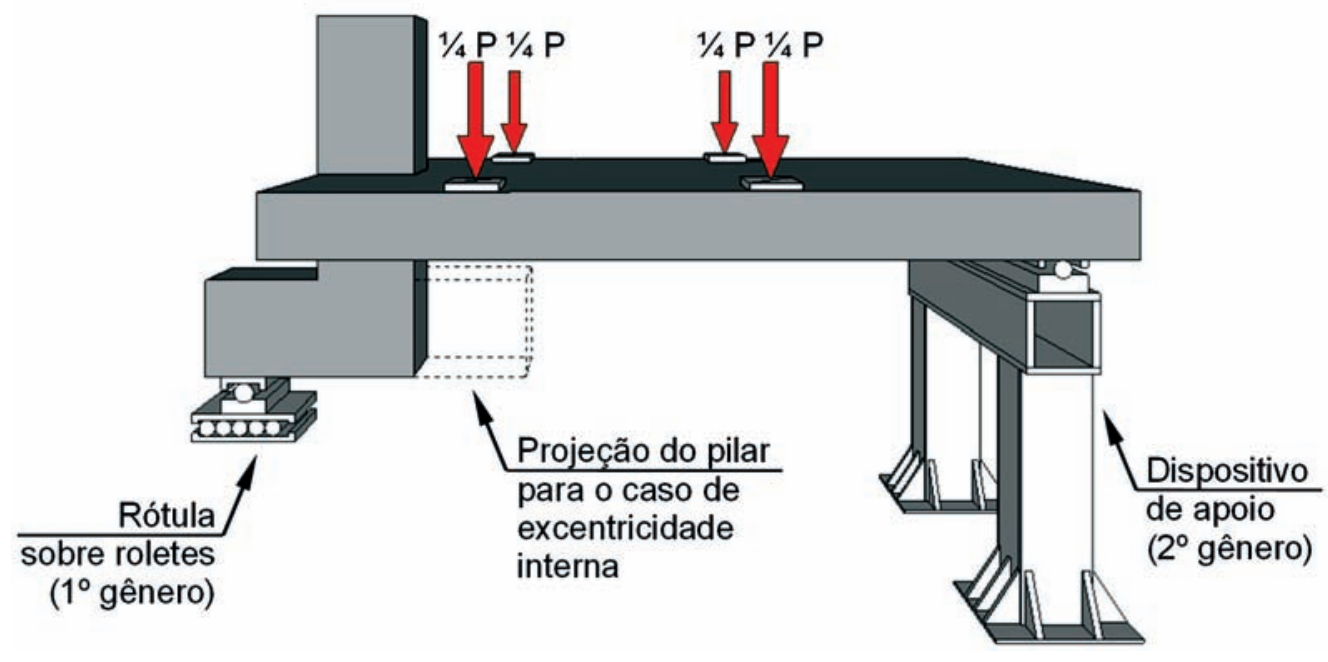


Structural performance assessment of reinforced concrete flat slab-edge column connections under the effects of outward eccentricity

Figure 4 - Flexural reinforcement at: (a) top; (b) bottom

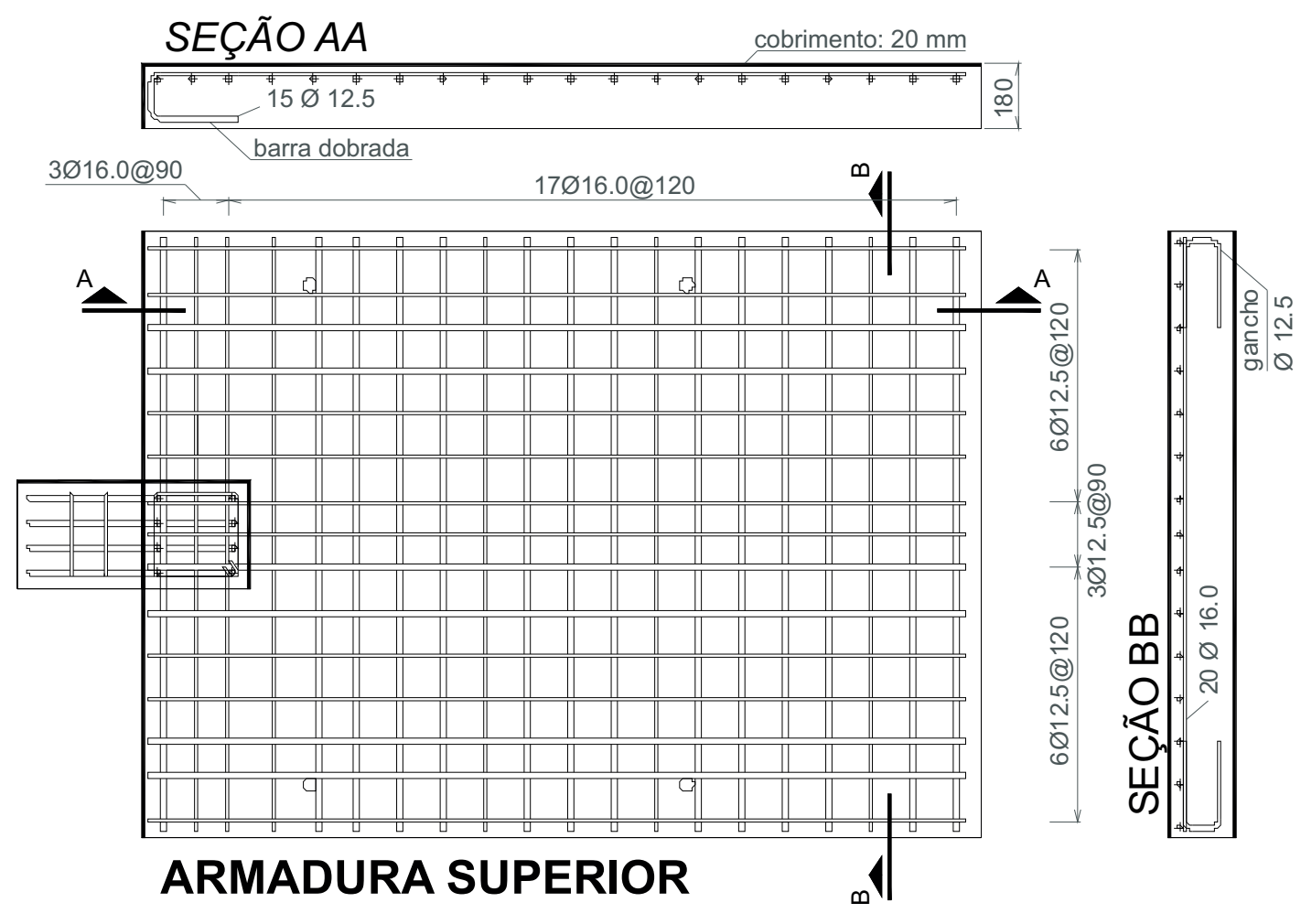

A

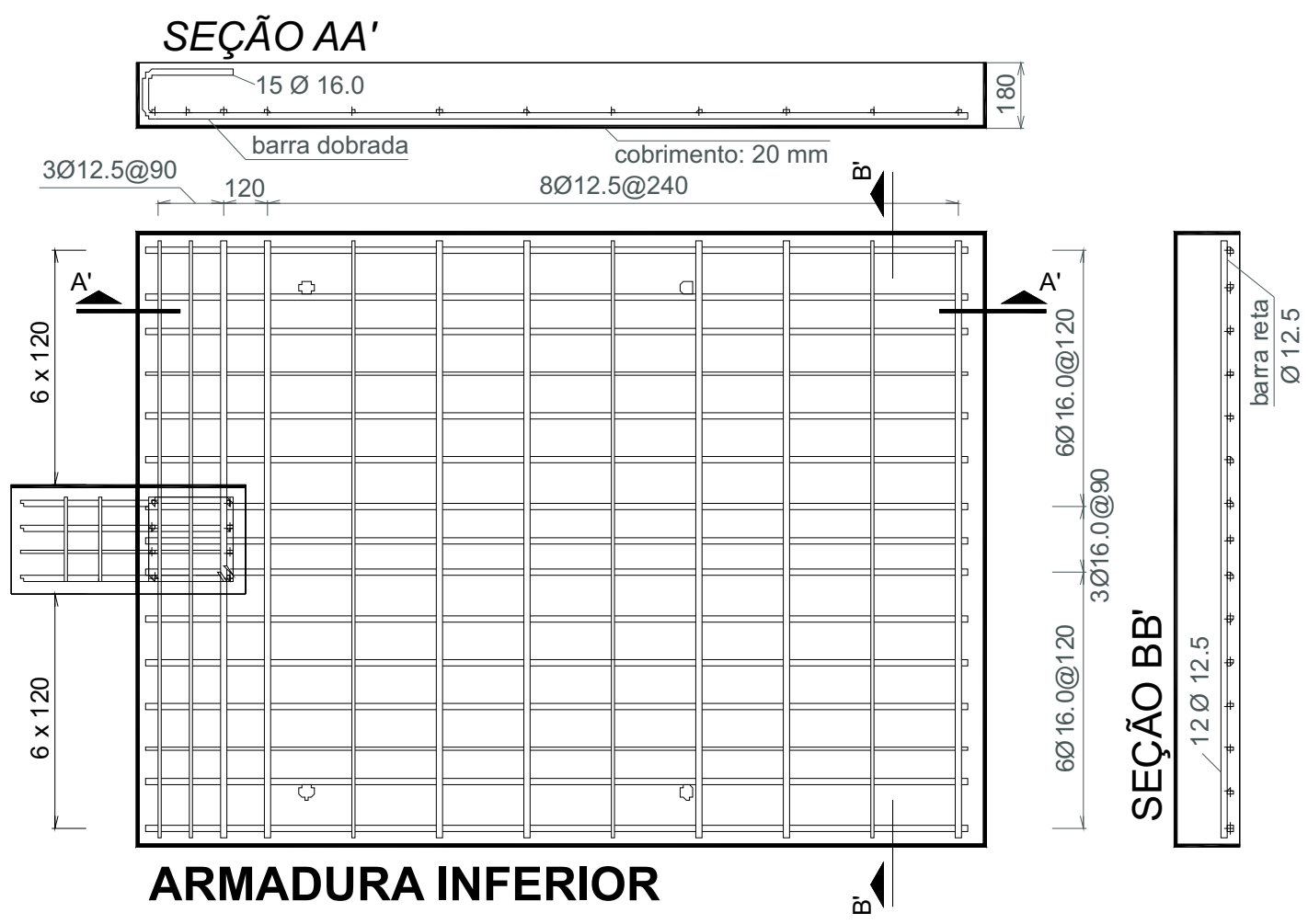

B 
Figure 5 - Schematic distribution of the reinforcement at the column and slab

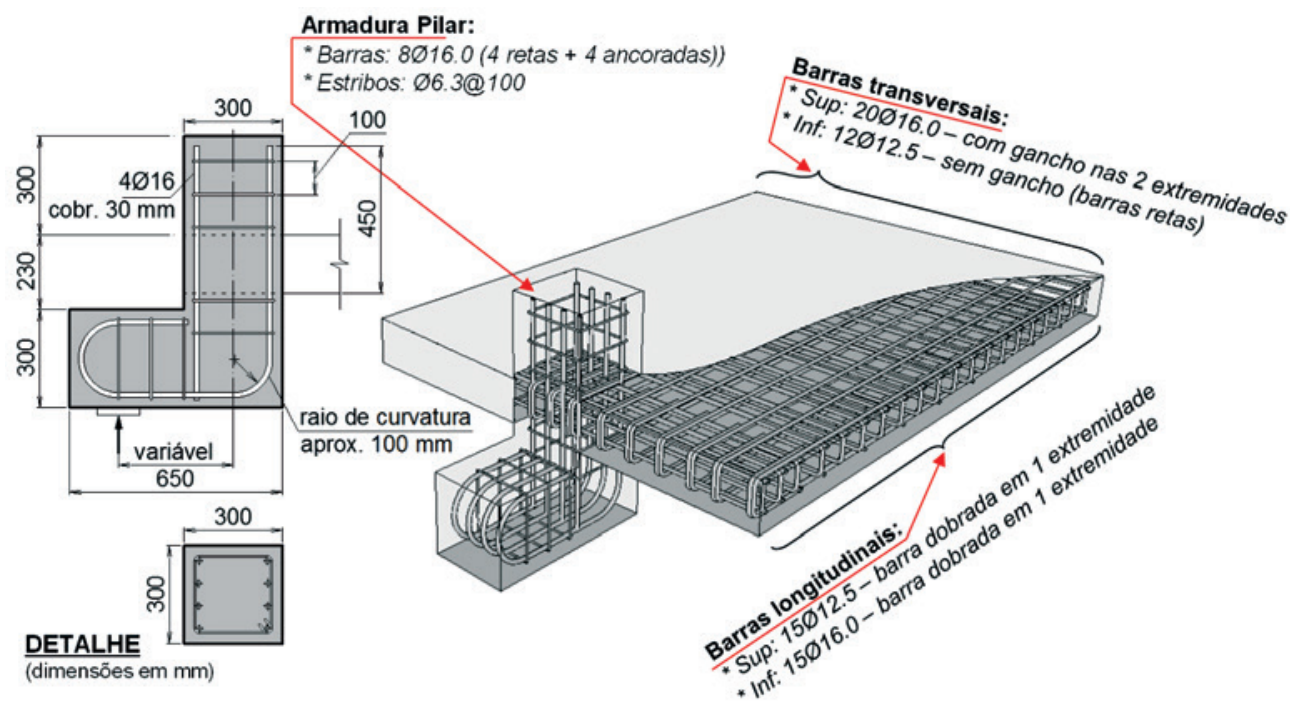

fore it was poured into the formwork by slump cone test resulting $12 \mathrm{~cm}$. Moulds were cleaned and oiled on all their contact surfaces and filled in layers with freshly mixed concrete for vibration using $25 \mathrm{~mm}$ diameter immersion vibrator and then curing. Compressive strength tests, split tensile tests and elastic modulus tests were carried out on 30 cylindrical samples (100 mm x $200 \mathrm{~mm}$ ) manufactured according to Brazilian standards NBR 5739 (2007) [6], NBR 7222 (2011) [7] and NBR 8522 (2008) [8], respectively.

\section{Figure 6 - Points of instrumentation}

\section{DEFORMAÇÕES NA} ARMADURA SUPERIOR

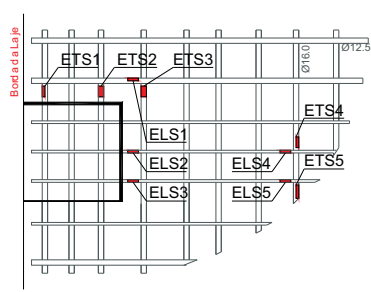

\section{DEFORMAÇÕES NA} ARMADURA INFERIOR

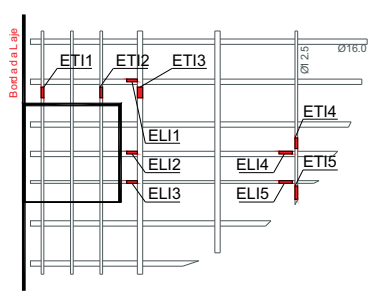

\section{DESLOCAMENTOS VERTICAIS}

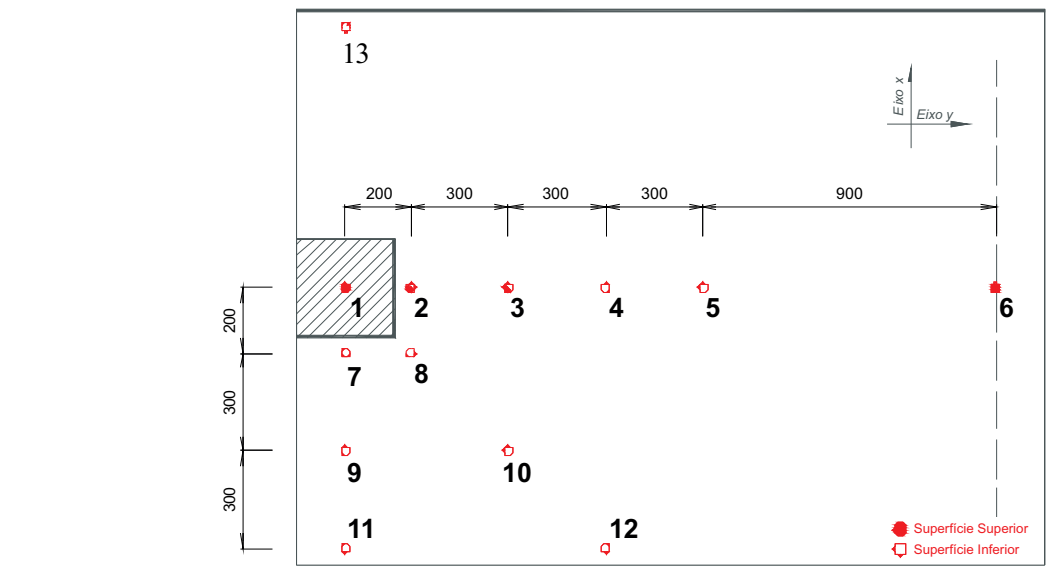

DEFORMAÇÕES NA SUPERFÍCIE DE CONCRETO

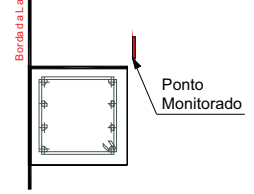

DESLOCAMENTOS HORIZONTAIS

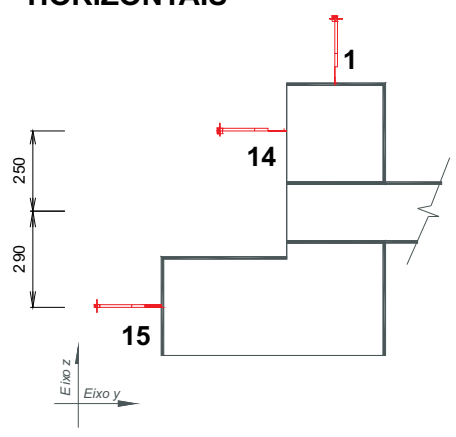



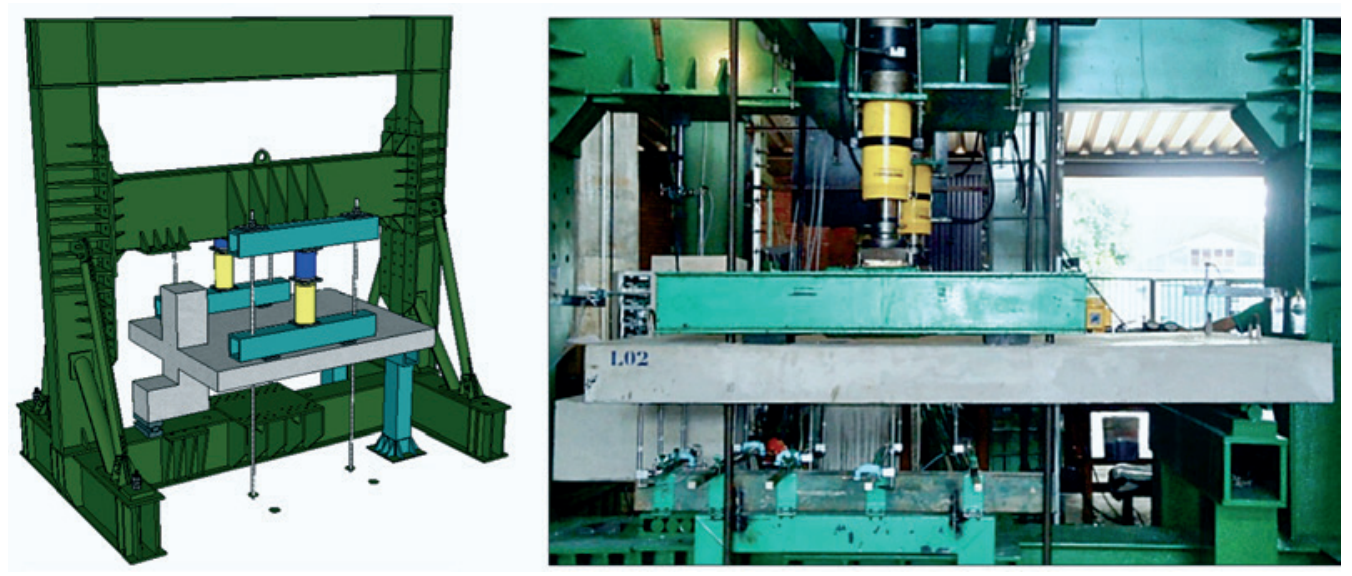

\subsection{Instrumentation of slabs}

To investigate the behaviour of the slabs during the test, measurements of strain on steel and on concrete surface as well as vertical and horizontal displacements have been collected at some strategic points that when mounted at the structure (Figure 6).

KYOWA electrical resistance strain gauges were attached to steel bars in order to determine the distribution of strain within the 20 instrumented points that contained two strain gauges glued on diametrically opposite sides, in both top and bottom reinforcement arranged on $\mathrm{x}$ and $\mathrm{y}$ axes; Strain in the concrete surface was also measured at different points by adapting them to rosettes, although part of the generated data have not

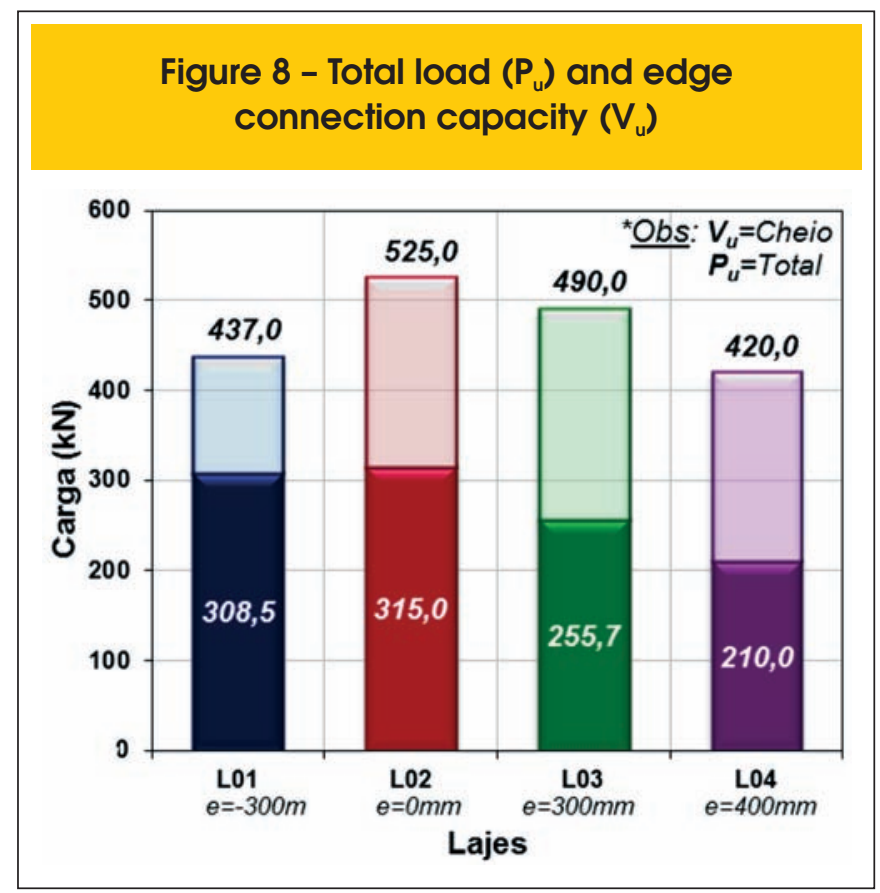

seemed consistent. Because in most cases strain gauges have failed in tension, there is some evidence of cracking, damage or detachment of the sensor, and for this reason, are presented just the results of the monitored point positioned at the column inner corner.

Vertical and horizontal displacements were measured with LVDTs (linear voltage displacement transducers) from HBM type WA50, whose output was recorded and stored electronically with good accuracy. For vertical displacements measurements 15 LVDTs monitored the deflections at characteristic points on longitudinal, transverse and diagonal axes, aligned at 45 degrees from the column inner corner, where most of them were mounted underneath the slab. In addition, column rotation was detected from relative horizontal displacements readings between top and bottom stubs. Aluminium targets were glued to the concrete surface to create a better surface for reading displacements.

\section{Testing procedures}

Measured data such as strains, displacements and applied loads were processed by HBM Catman [9] software associated to HBM Spider 8 data acquisition system. All 68 channels of 9 modules were used, being controlled by 2 computers that recorded all electronic test data from LVDTs (15), steel strain gauges (40), concrete strain gauges (9) and load cells (4).

The load applied by the hydraulic jacks was monitored by the conjugated KRATOS $1,000 \mathrm{kN}$ capacity load cells, that were used only to control the pump operation. The four remaining hollow load cells, from HBM type C6A, were attached to the tie rods for parity checks and reading of data redundancies.

Oil flow was driven by electric pumps, which powered two Enerpac hydraulic actuators that transmitted loading to the piston/rod assembly and, subsequently, distributed the load equally to slab by four thick steel plates. The test was carried out on the specimens incrementally up to failure, using the reaction frame anchored to the Structures Lab strong floor at the University of Brasilia. The load application system is shown in Figure 7. 


\section{Results and discussions}

\subsection{Ultimate loads and failure modes}

The test results were analysed and compared through tables and graphs. Table 2 summarizes the observed failure modes at ultimate loads, where $V_{u}$ corresponds to the column support reaction (or connection capacity), calculated statically in the longitudinal direction, and $\mathrm{P}_{u}$ is the total load applied to system, considering slabs' self-weight and equipment's loading.

By comparing the results of the connection capacity $\left(V_{u}\right)$ shown by L1 and L3 it confirms the hypothesis of an outward eccentricity is more critical than inward since, although they have the same value of eccentricity, the column support reactions $\left(\mathrm{V}_{\mathrm{u}}\right)$ corresponds, respectively, to $308.5 \mathrm{kN}$ and $255.7 \mathrm{kN}$, repre- senting a decrease of $17.1 \%$. A larger amplitude of total load resisted by L1 is explained by the test setup, in which the continuous pin support located on the opposite side to the column edge attracts a smaller proportion of the load. Yet, comparing systematically $V_{u}$ of L2, L3 and L4, it seems that increasing the outward eccentricity leads to a reducing on the connection load capacity. Confronting the two cases of outward eccentricity, L3 and $\mathrm{L} 4$, the addition of $100 \mathrm{~mm}$ to the eccentricity imposed a reduction by $17.9 \%$ to the connection load capacity. Figure 8 illustrates this behavior.

Unlike L1 and L2, which failure were abrupt and not preceded by an increase in the deflection, specimens L3 and L4 with outward eccentricity have shown that failure modes were mainly determined by transferring load than by shear, even though failure has led to the formation of the punching cone at the end of the test.

Figure 9 - Relationship between load and strain of longitudinal top bars

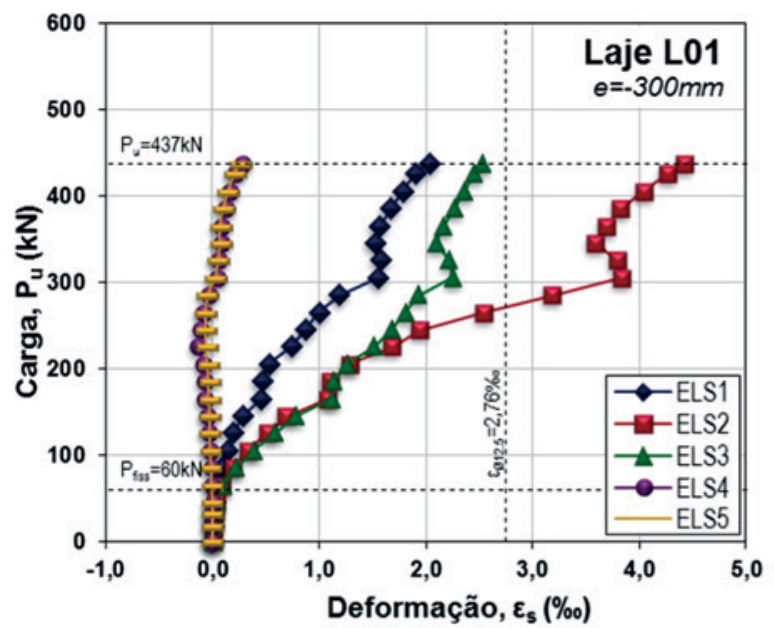

A $\operatorname{L01}(\mathrm{e}=-300 \mathrm{~mm})$

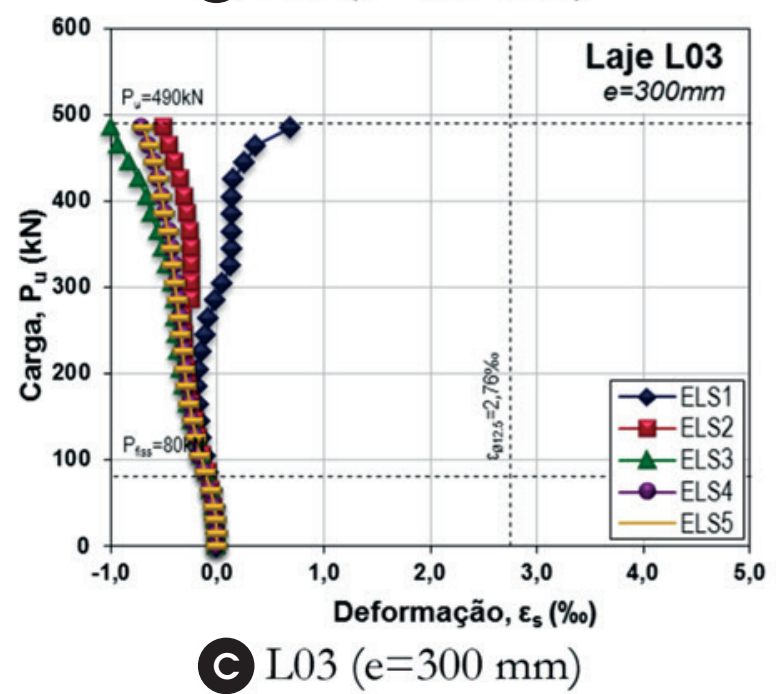

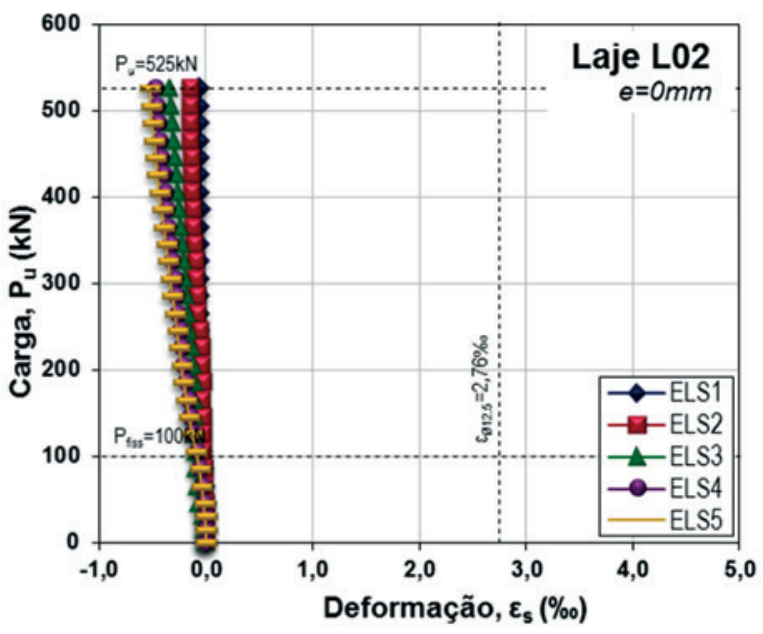

B $\mathrm{L} 02(\mathrm{e}=0 \mathrm{~mm})$

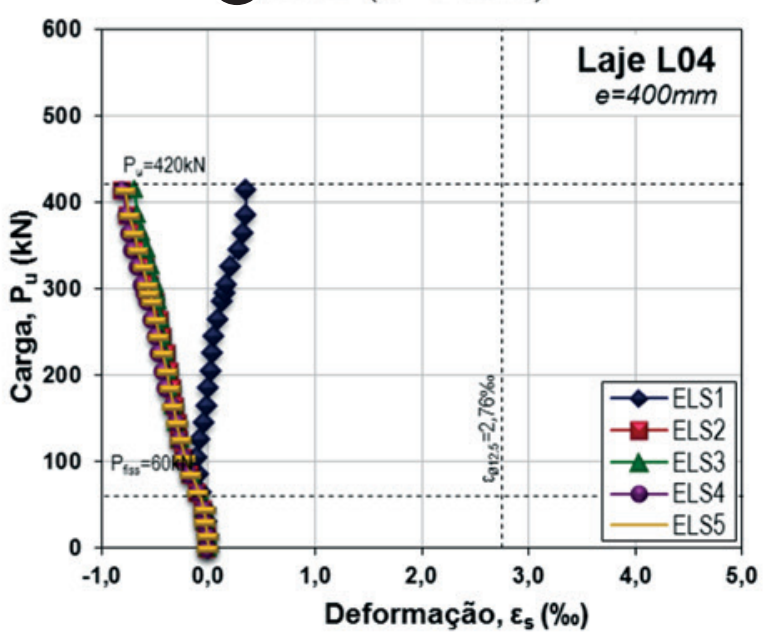

D L04 $(\mathrm{e}=400 \mathrm{~mm})$ 


\subsection{Strains on flexural reinforcement}

Reinforcement strains are presented in the graphs of Figure 9 to Figure 12, being plotted against the applied loads at the predefined points of instrumentation, where is indicated the first visible crack load, the failure load as well as the yield strength correspondent to the rebar of same diameter.

It was observed that the gauges on the top longitudinal bars, ELS, and top transverse bars, ETS, presented predominantly tensile strains in L1, being worth emphasizing that the column was subjected to an inward eccentricity and so vertical loading also caused tension to slab edge in both longitudinal and transverse directions at the near region of the column. Higher strains can easily be seen in the column longitudinal axis near its front face, with bars reaching yield strain. Top transverse strains in L1 were also accentuated next to the column front face.
For slabs with outward eccentricity, the highest strains were collected at the gauges located on the bottom longitudinal bars, ELI, and top transverse bars, ETS, indicating a "horse saddle" effect, given its overall deformed shape. As for the slab L1 (i.e., with no eccentricity), it exhibited an intermediate behaviour between both cases.

Thus, for L2, L3 and L4, the predominance of the effects on the longitudinal direction were within the column strip, where the slab was subjected to a positive bending moment, since its bottom fibres were in tension and top fibres in compression. This behaviour is confirmed by L2, L3 and L4 load-strain graphs at the top longitudinal reinforcement, showing that by increasing eccentricity the higher are the strains around the column region, as the applied moment is greater. Only ELS1 on slabs L3 and L4 presented compressive strains, which can be explained by the fact that this gauge

Figure 10 - Relationship between load and strain of longitudinal bottom bars
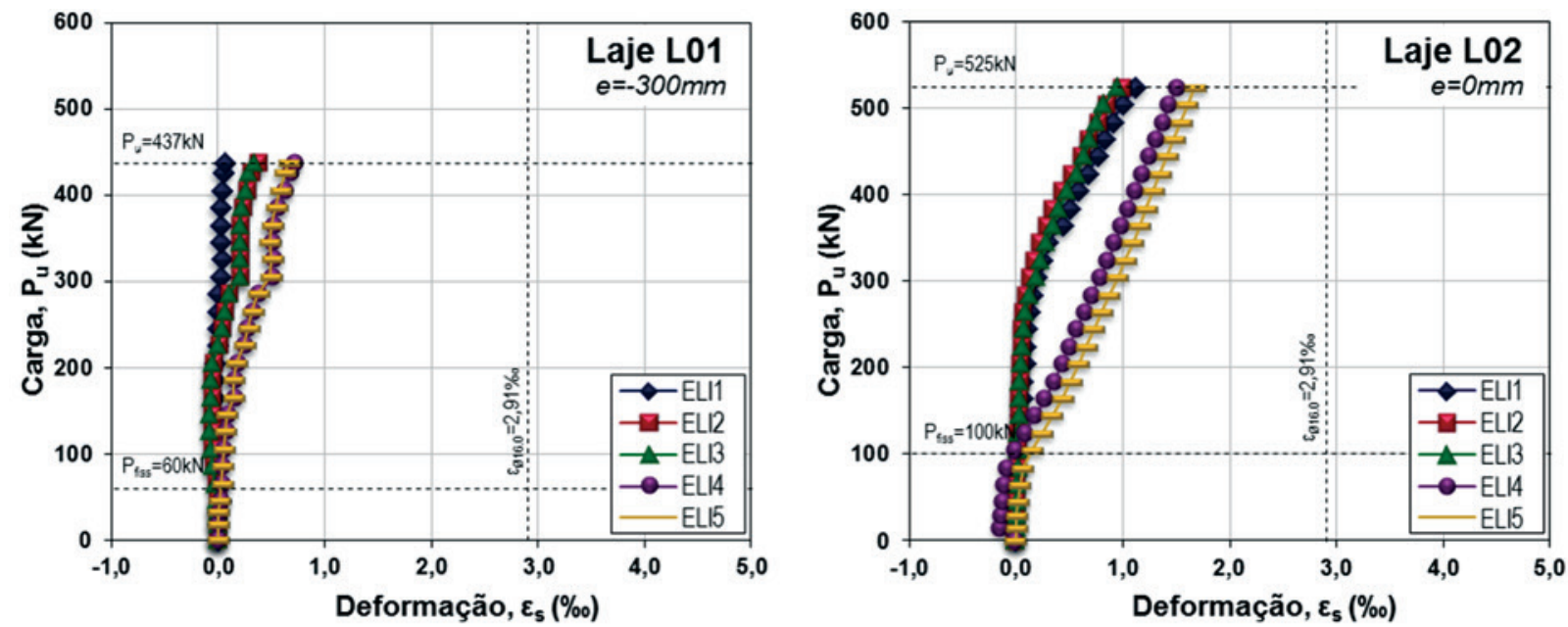

A L01 (e=-300 mm)
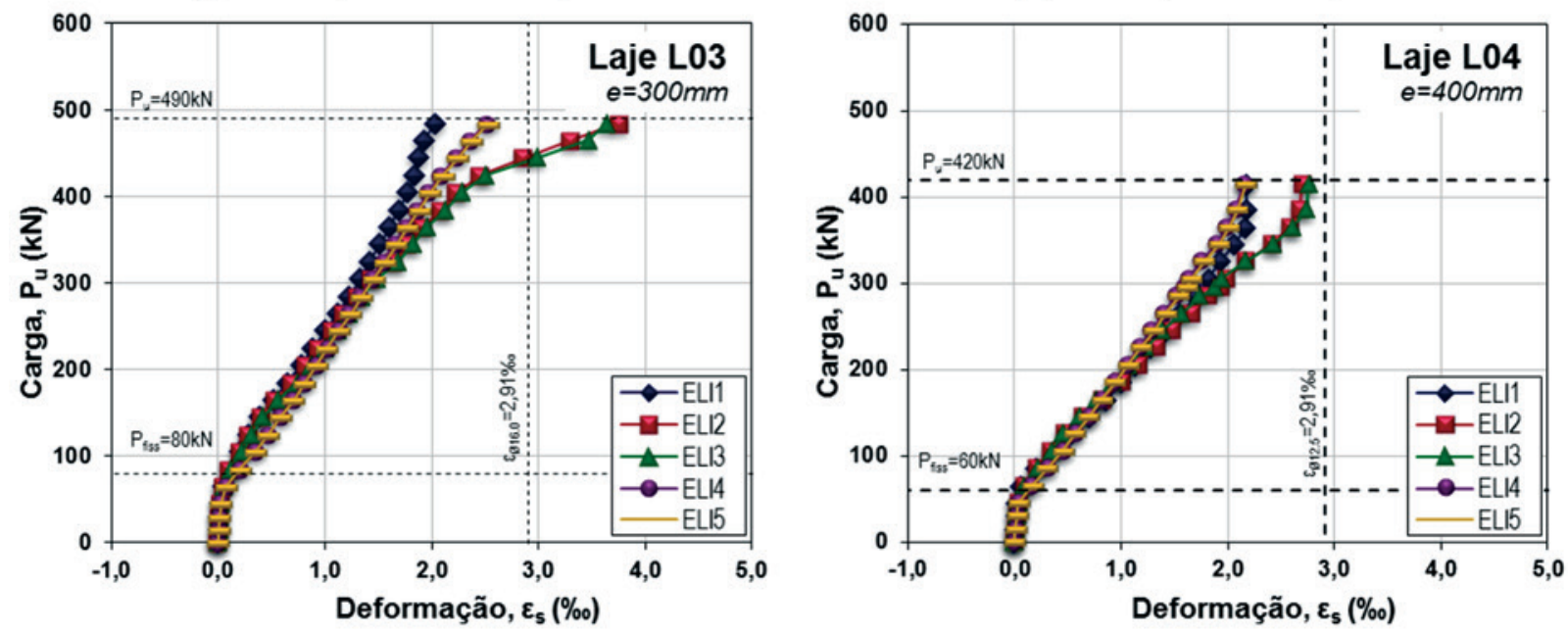

C L03 $(\mathrm{e}=300 \mathrm{~mm})$

D L04 (e=400 $\mathrm{mm})$ 
was not located at bars crossing the column, so they were subject to the influence of bars on the other direction.

Load-strain graphs of L2, L3 and L4 at the top transverse bars show that the arrangement of the vertical loads generated only negative bending moment in all cases, so that tensile strain near the slab edge or next to the column frontal face may vary to a greater or lesser extent depending on the column rotation due to the eccentricity direction. As for the bottom transverse reinforcement, the graphs revealed that strain at top and bottom bars had the same sign convention in various sections of the slab. For L1 it happened to almost all instrumented points along the longitudinal direction. For L2, whose column had no moment, even presenting lower strains along the longitudinal direction, all top and bottom strains had opposite signs. The eccentricity and, consequently the column rotation, had just limited more or less the strains closest to either outside or inside (frontal) faces of the edge column.

\subsection{Strains on concrete surface}

Another graphic was constructed to represent the concrete strains versus applied load at the point where monitoring was more efficient (Figure 13). Only a gauge glued in the transverse direction presented comparable compression strains for all slabs, according to what had been explained about the slabs behaviour in connection with the gauge on steel bars.

Comparing the results of the strain gauges aligned to the column frontal face in the transverse direction is was noticed that with an increasing eccentricity to outwards, readings developed into larger strains, being higher in L3 and L4, falling by half for the same load level in

Figure 11 - Relationship between load and strain of transverse top bars
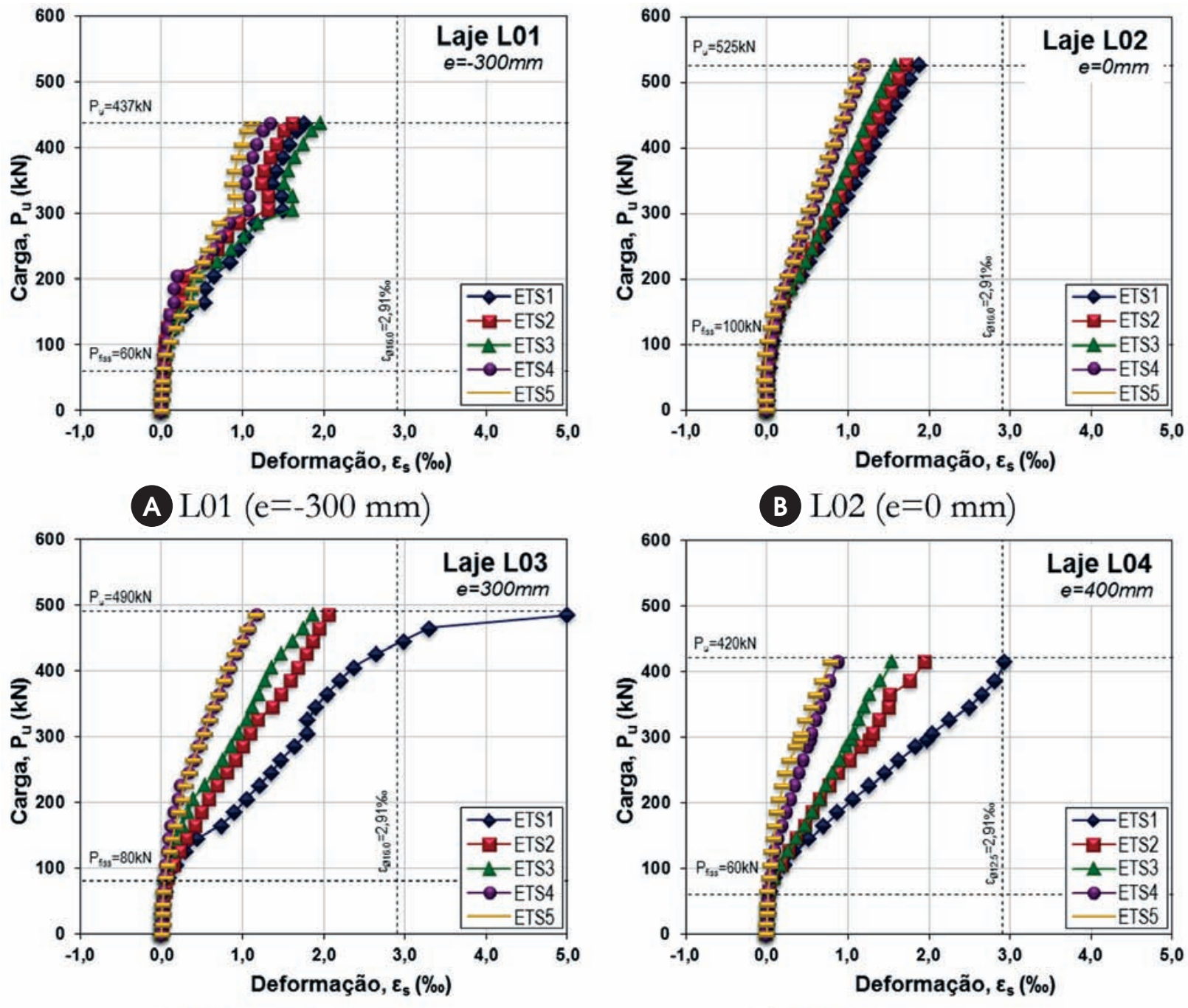

C L03 $(\mathrm{e}=300 \mathrm{~mm})$

D L04 (e=400 mm) 
$\mathrm{L} 2$, and then to a lesser extent in L1, when starts to deviate from the trend and reach positive values, caused by intense local cracking. The maximum strain observed was close to $-1.5 \%$ for $L 3$ and $L 4$, though, it should be noted that, among the collected data that remained consistent on other points not related here, the larger strains on concrete surface occurred near the inner corner of the column axially placed at 45 degrees, reaching values that exceeded $-1.5 \%$.

\subsection{Column rotations}

From the relative values of horizontal displacements measured at LVDT 14 and LVDT 15, it is observed that column rotates in different directions, according to the applied eccentricity which was given to the supporting point. The only specimen that reproduced inward eccentricity, $L 1$, developed a rotation towards the outer direction with respect to the slab, as it moved the axis of rotation away from the column centre. Despite the column of L2 is not subjected to significant bending moments, the continuity of the slab-column connection contributes in its rotation, causing it to pivot but in a small magnitude range towards the inner direction of the slab. As for the outward eccentricity specimens, results indicated that increasing the eccentricity implies a larger column rotation. However, it must be noted that as ultimate load of L4 is less than L3, the latter is allowed to rotate up to a higher level of loading, reaching higher values.

The development of the angle of column rotation can be seen in the graph of Figure 14, which represents the column rotation against load. It is apparent that the absence of eccentricity lead to a more acclivitous curve of the connection's rotation capacity, and also states that, for the same load level, the increase of outward eccen-

\section{Figure 12 - Relationship between load and strain of transverse bottom bars}

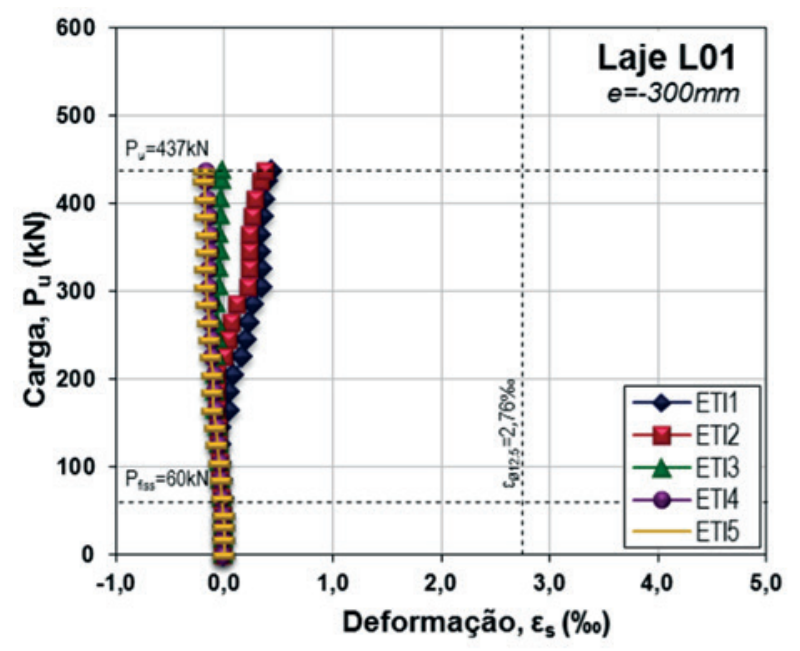

A L01 $(\mathrm{e}=-300 \mathrm{~mm})$

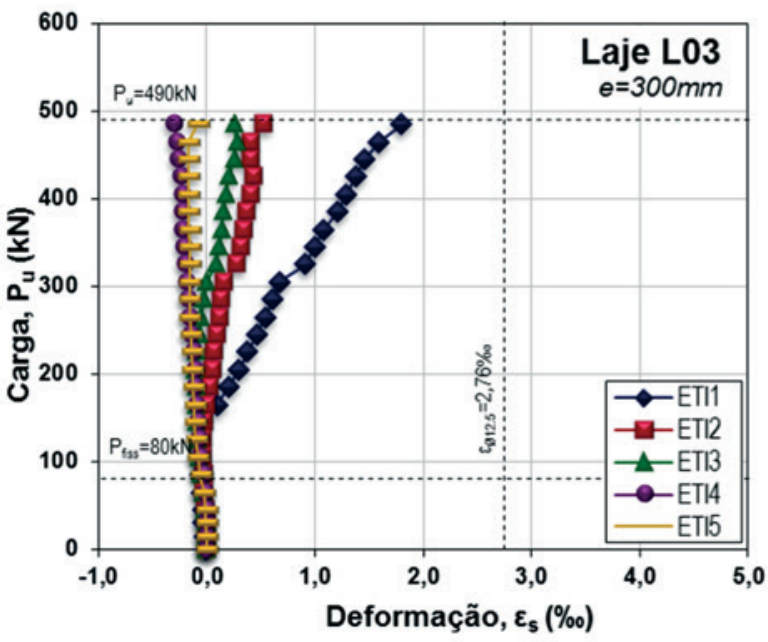

C $\mathrm{L} 03(\mathrm{e}=300 \mathrm{~mm})$

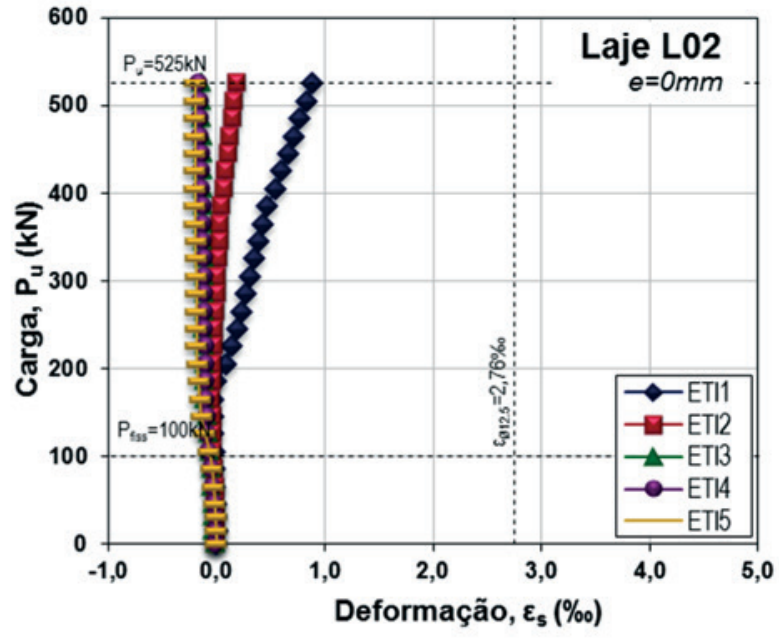

B $\mathrm{L} 02(\mathrm{e}=0 \mathrm{~mm})$

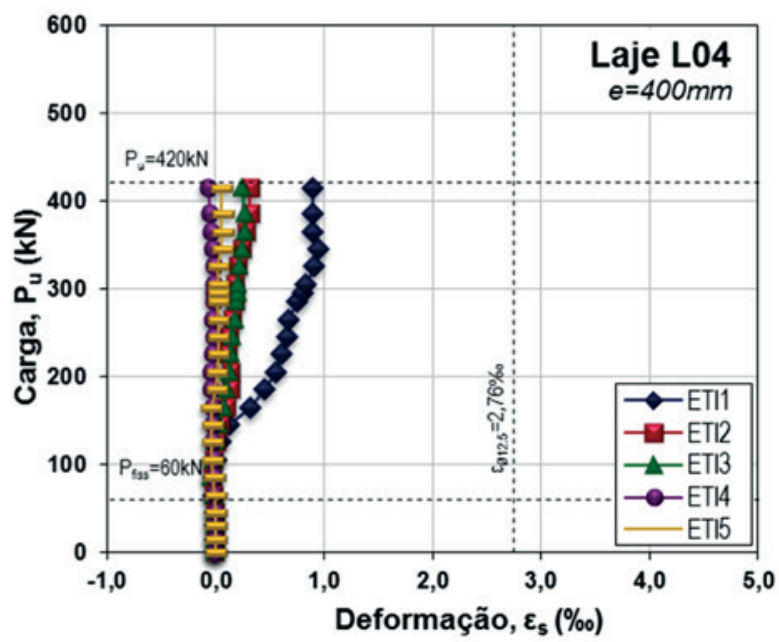

D L04 (e=400 mm) 

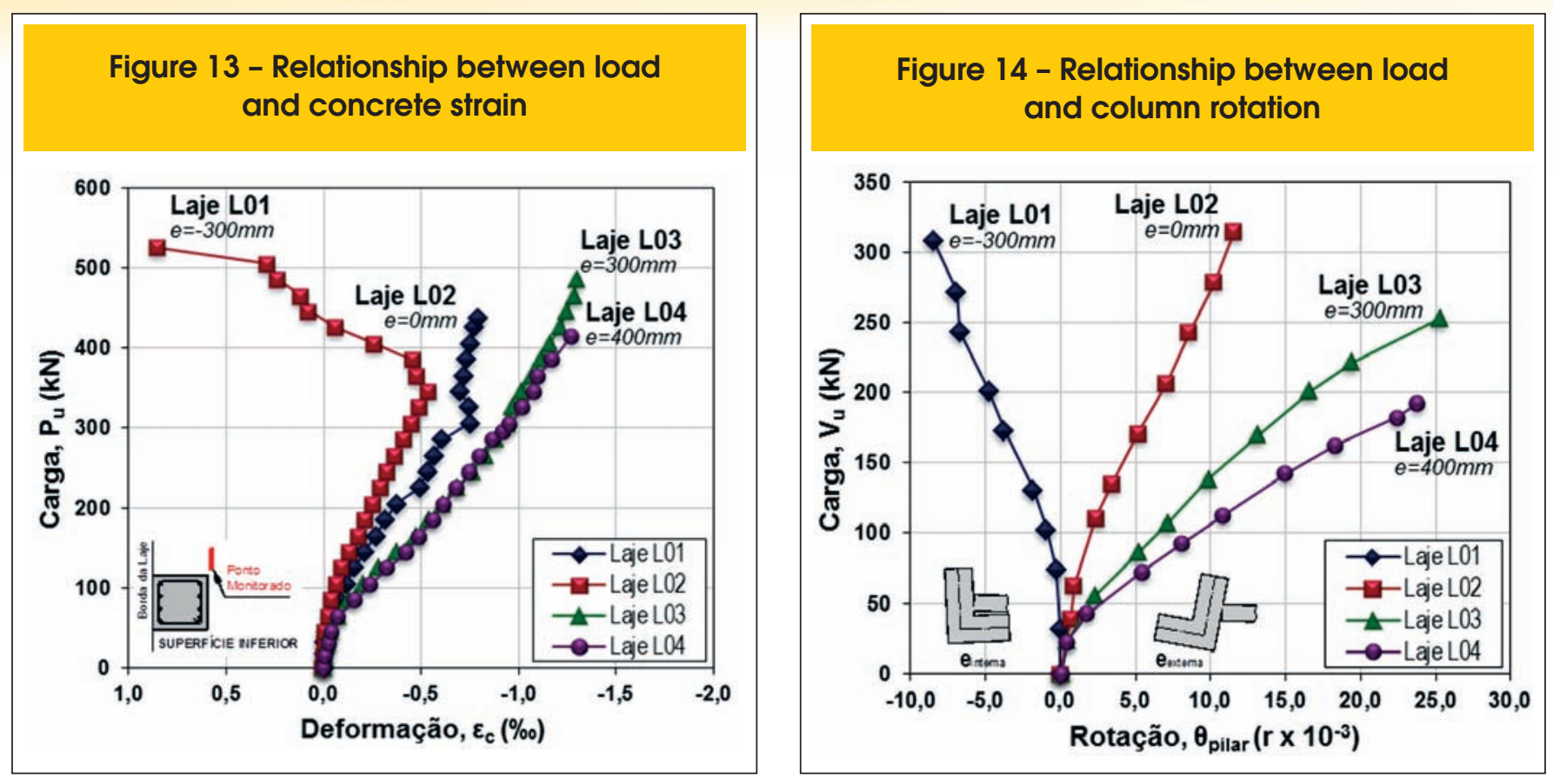

Figure 15 - Vertical displacements along the longitudinal axis of the slab
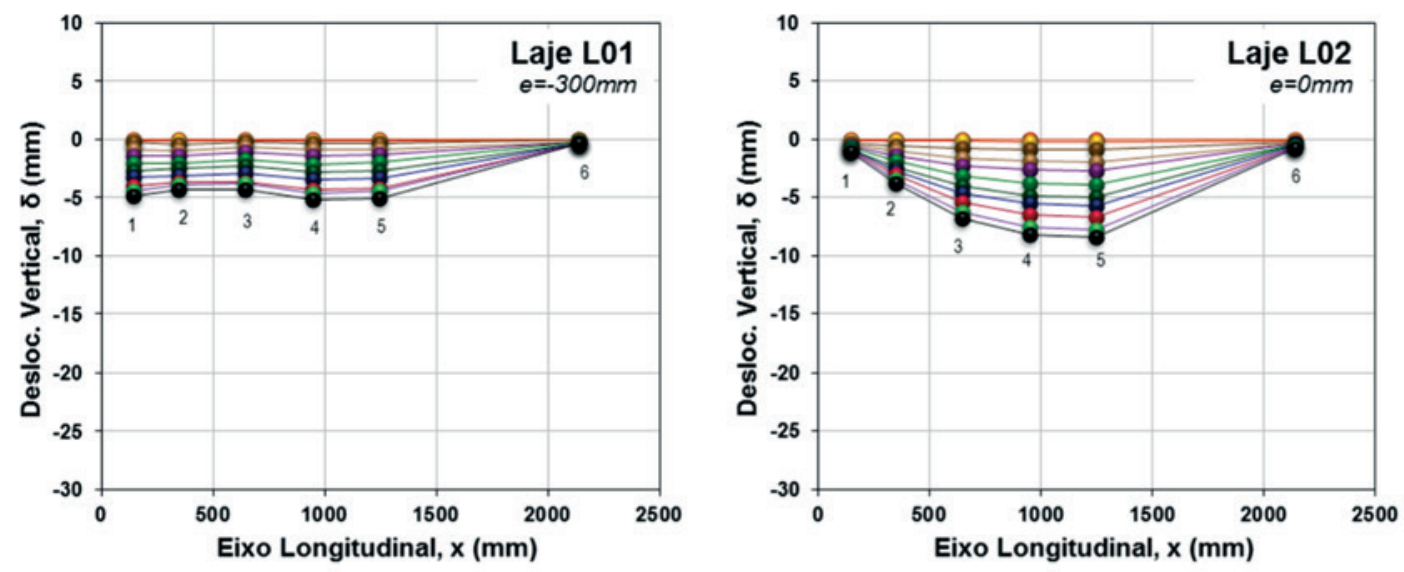

A L01 $(\mathrm{e}=-300 \mathrm{~mm})$

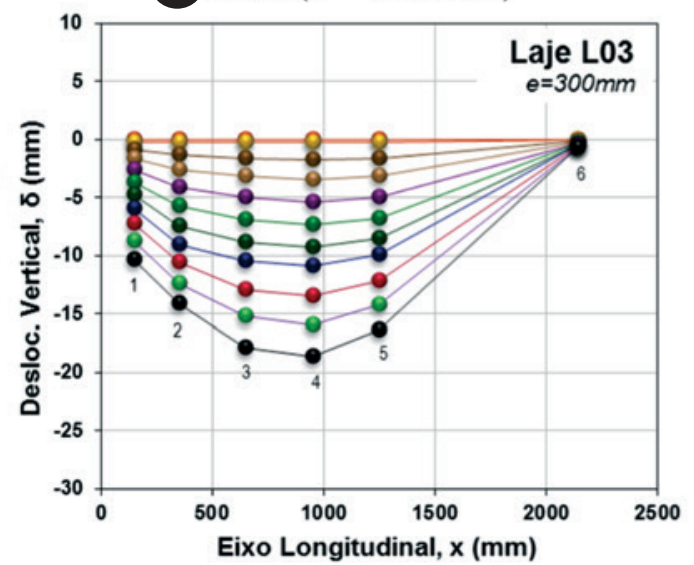

B $\mathrm{L} 02(\mathrm{e}=0 \mathrm{~mm})$
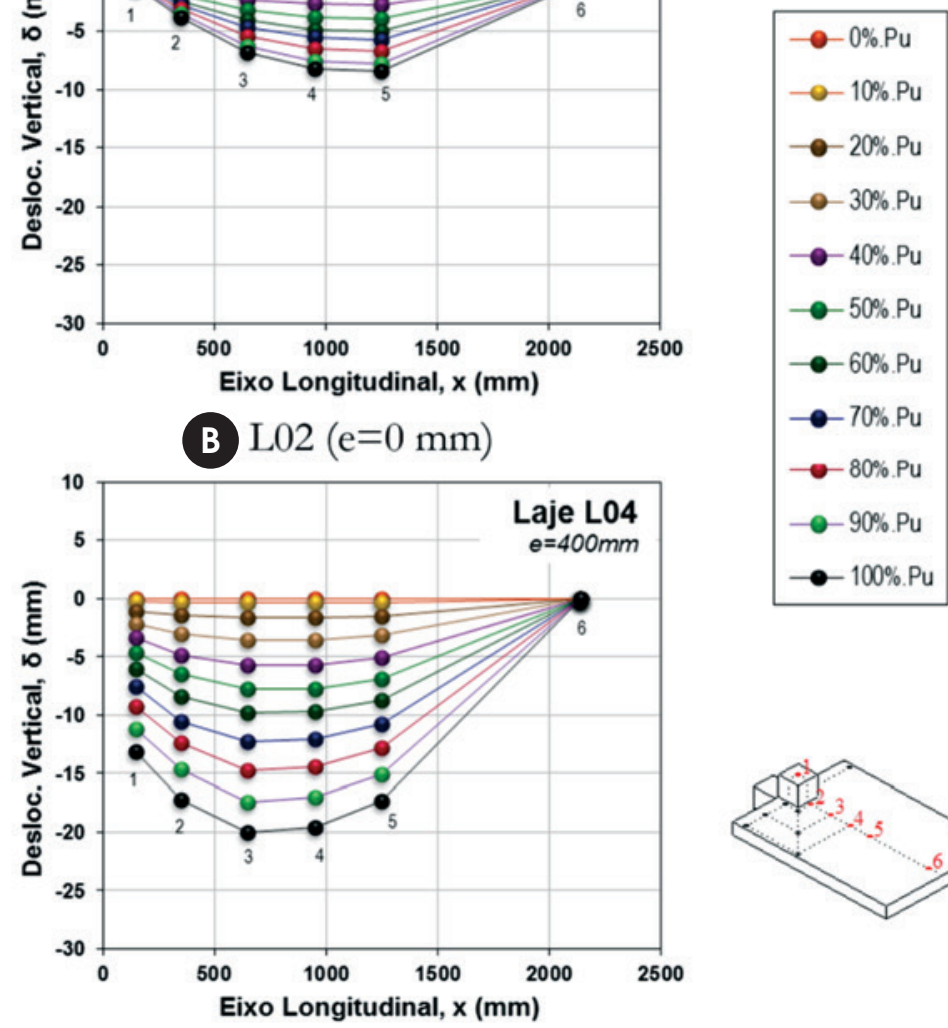

C $\operatorname{L03}(\mathrm{e}=300 \mathrm{~mm})$

D L04 (e=400 mm) 
tricity caused the column to rotate more quickly, compared to inward.

\subsection{Vertical displacements}

As for the vertical displacements, the deflected shape is graphically shown along the longitudinal axis (Figure 15) and transverse axis (Figure 16), both aligned on the centre lines of the column and also along the diagonal axis (Figure 17), aligned at 45 degrees from the column inner corner.

The graph of vertical displacements along the longitudinal axis for L1 shows that with the application of load, inward eccentricity caused the column to move downwards and rotate towards the outer direction of the slab, inducing a slight upward movement in the region nearby the frontal face of the column. Vertical displacements along the transverse direction of $\mathrm{L} 1$ have shown that due to the direction of the column rotation, displacements along the edge strip of the slab were more pronounced than its perpendicular direction.

Slabs L2, L3 and L4 presented a similar displacement pattern among each other, increasing the magnitude of the displacements the larger the eccentricity was. Regarding L3 and L4, the slabs have deflected significantly up to the formation of the failure punching cone. Furthermore, it was apparent that larger eccentricities generated considerably increased displacements measured above the column in relation to its adjacent points in both directions, giving evidence of possible torsion on the edge connection. It was observed that the point monitored by the LVDT 13, although it should be ideally mirrored to LVDT 11, showed considerably higher values. However, by disregarding these measurements, it can be observed for all slabs that the largest displacements occur in the diagonal axis just below the loading plates (LVDT 12). Another possible observation include that the highest magnitude point tends to move from the slab mid-span towards to the edge connection vicinity along the longitudinal axis.

\subsection{Cracking pattern}

Figure 18 illustrates the slabs resulting cracking pattern after fail-

Figure 16 - Vertical displacements along the transverse axis of the slab
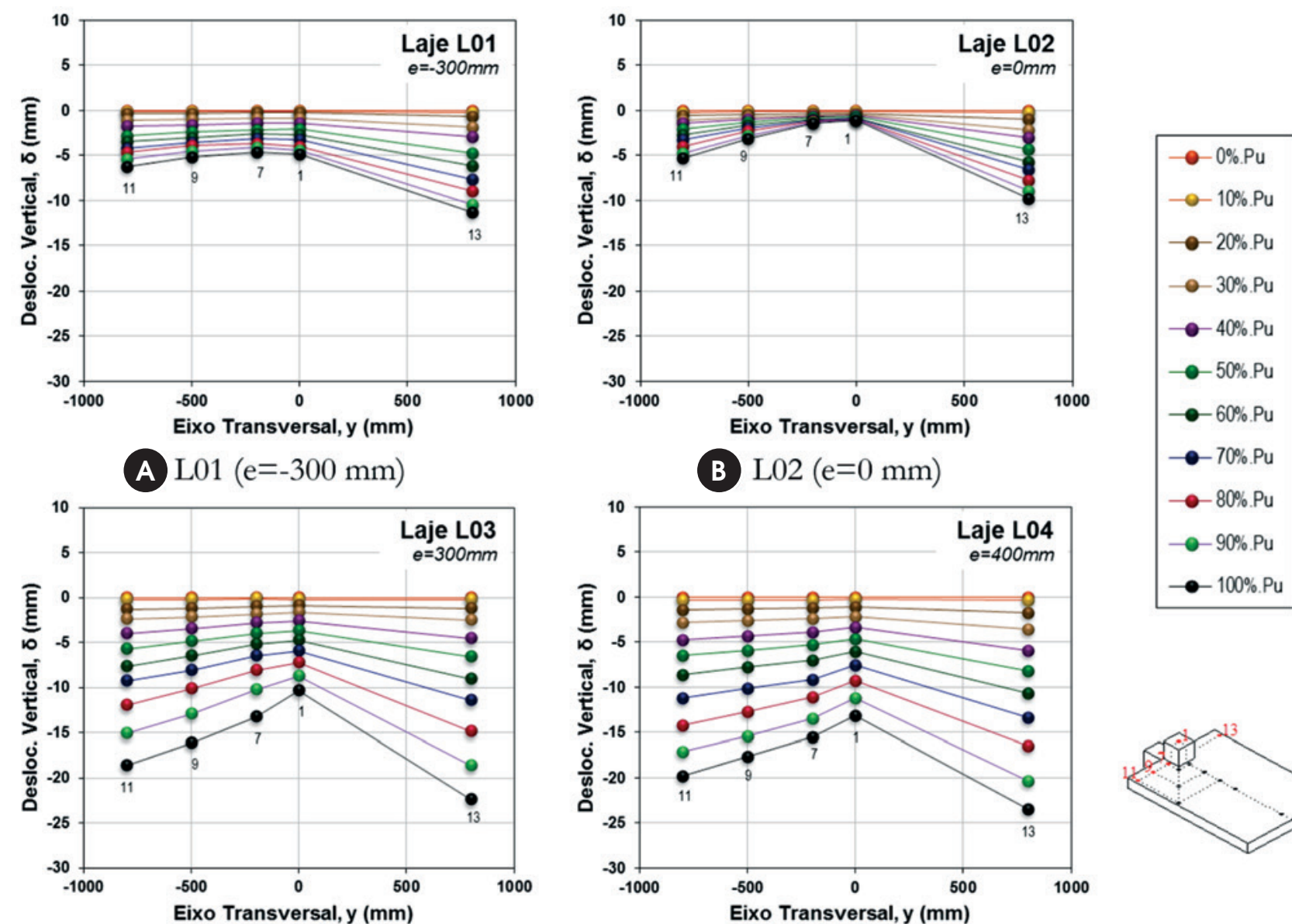

C $\operatorname{L03}(\mathrm{e}=300 \mathrm{~mm})$

D $\mathrm{L04}(\mathrm{e}=400 \mathrm{~mm})$ 
ure, checked on both top and bottom surfaces, particularly the region nearby the edge connection since, in general, cracks followed paralleled to the alignment of the reinforcing bars on regions far from connection.

On top surface of the slab, L1 presented the first visible crack in the vicinity of the frontal face of the column at an applied system load of $60 \mathrm{kN}$, while the region next to the lateral faces of the column began to crack at a load of $100 \mathrm{kN}$. Some apparently torsional cracks were also observed, beginning at the sides of the column, following after diagonally to the slab edge and then developing through the slab thickness to converge on more distant points. These cracks occurred only in this specimen, which can be explained by the direction of rotation of the column.

Analogously to L1, a higher concentration of cracks occurred in L2 next to the column frontal face. However, in this specimen, cracks that were guided toward the slab edge had a minor slope. The first visible crack occurred at a load of $100 \mathrm{kN}$, also close to the frontal face of the column, while in the vicinity of the column sides crack occurred only at $180 \mathrm{kN}$.
L3 and L4 showed cracking pattern very similar to each other, where some cracks developed diagonally to the slab edge, although in the opposite direction L1. In these specimens the failure cone were formed closer to the column frontal face, especially in L4, which appears to be due to eccentricity. L3 specimen exhibited first cracks at a load of $60 \mathrm{kN}$ and $100 \mathrm{kN}$, respectively, near frontal and lateral faces of the column, while L4 cracked at $80 \mathrm{kN}$ and $160 \mathrm{kN}$.

All specimens showed similar behaviour considering the bottom surface of the slab. By dividing the slab into three longitudinal segments, the inner segment showed predominantly transverse cracks, while in the other two segments, cracks were inclined up to the edge, indicating the presence of torsion due to a different bending behaviour of the slabs in two directions.

\section{Conclusions}

Due to the small number of tested specimens, the results cannot be taken as conclusive, although it shows quite enlightening

Figure 17 - Vertical displacements along the diagonal axis of the slab
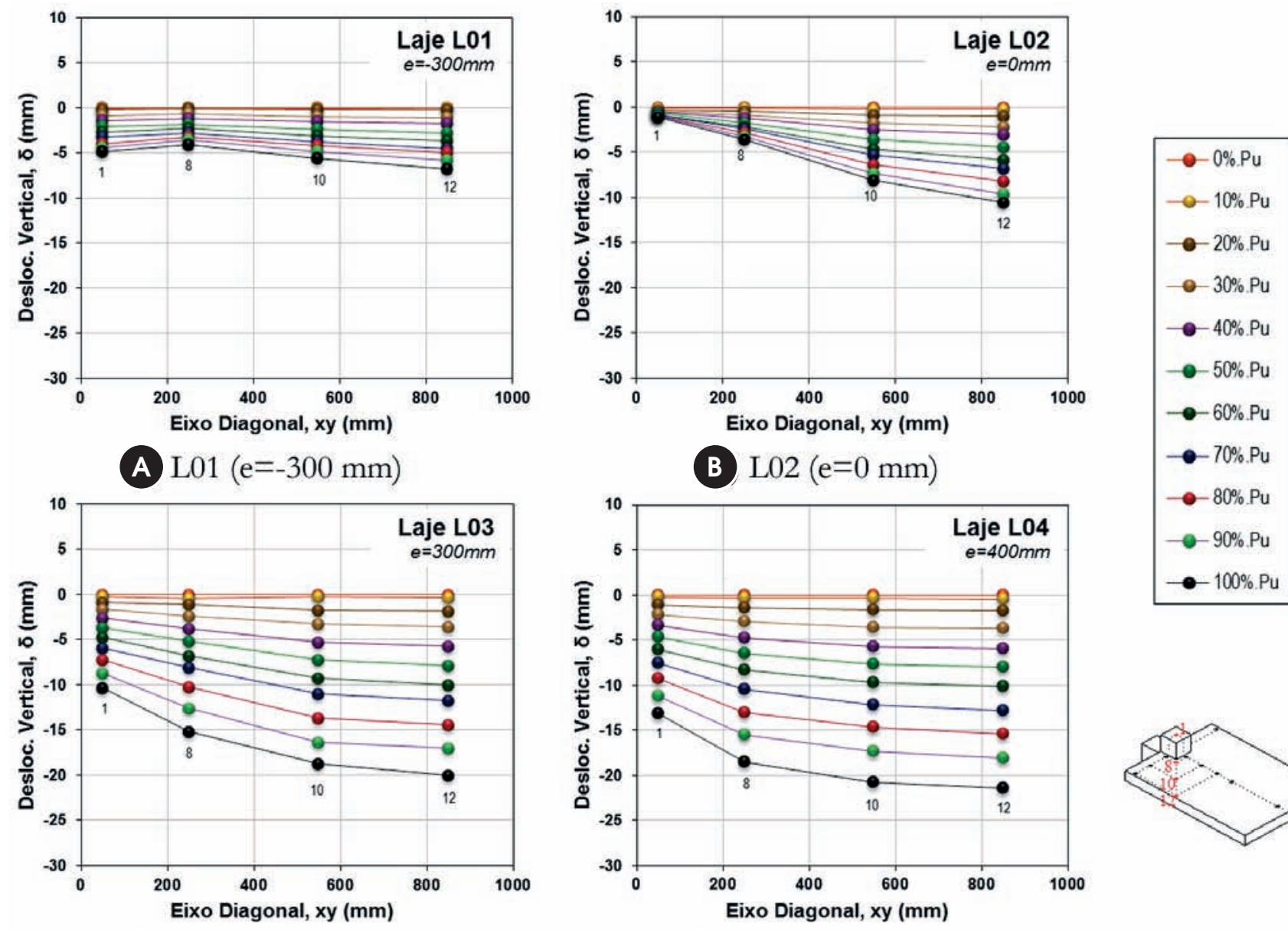

C $\operatorname{L03}(\mathrm{e}=300 \mathrm{~mm})$

D L04 (e=400 mm) 
indicatives of edge connections behaviour subjected to outward eccentricities. Points of instrumentation provided representative data from the tested slabs, which were useful in accomplishing the analysis on the eccentricity effects on slabs' behaviour. By monitoring both the top and bottom bars at the same section, it was possible to verify the strains distribution at different cross sections, compensating, to some extent, the lower efficacy of the concrete gauges glued to the slabs' soffit, which may not followed the struts directions.

Thus, among the possibilities that can be attributed to the influence of outward eccentricities on the connection strength, it was found that for large outward eccentricities: cracks' opening level is relatively higher than cases of inward eccentricities; torsional crack reaches the free edge on farthest points of connection; concrete strains are comparatively more pronounced; punching failure cone is apparently developed closer to the front face of the column; the largest displacement along the longitudinal axis is movable, tending to get closer to the edge connection as the eccentricity increases; ultimate failure loads are much more penalized in connections subjected to outward eccentricities than inward ones.

\section{Acknowledgements}

The authors would like to thank Prof. PE Regan, Emeritus Professor at the University of Westminster (London, UK), for the valuable theme suggestion and throughout this research, as well as the Brazilian Scientific and Technological Research Funding Agencies, CNPq and CAPES for the financial support.

\section{References}

[01] WIGHT, J. K.; MACGREGOR, J. G. Reinforced Concrete: Mechanics and Design. New Jersey, NY: Prentice Hall, 6ed, 2011, 1157p.

[02] NARASIMHAN, N. Shear reinforcement in reinforced concrete column heads, London, 1971, Thesis (PhD) - Faculty of Engineering of University of London, Imperial College of Science and Technology, 267p.

[03] REGAN, P.E. Tests of Connections between flat slabs and edge columns, London, 1993, School of Architecture and Engineering, University of Westminster.

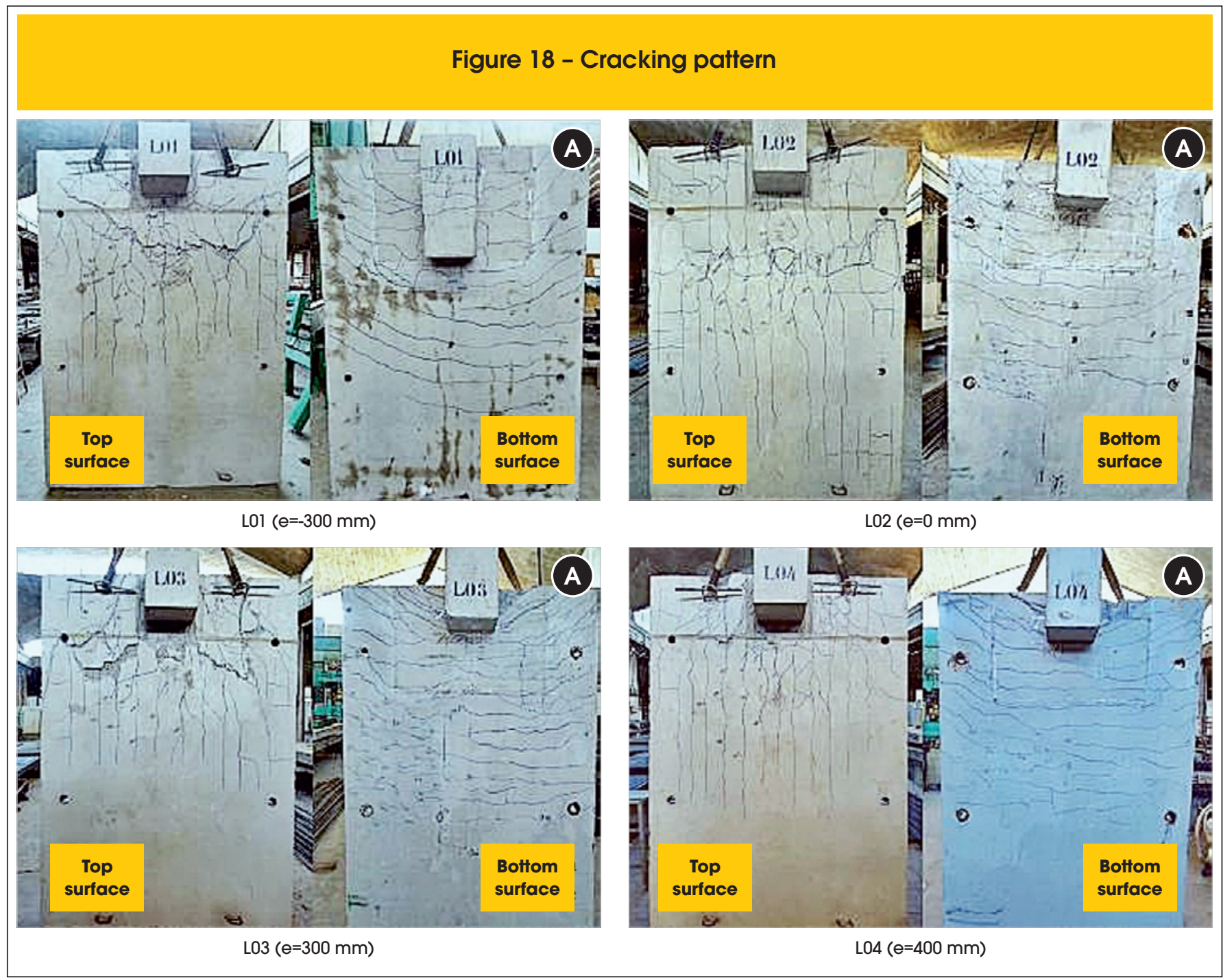


[04] FELICIANO, F. M. H. Punção em lajes lisas de concreto armado com pilares de borda e excentricidade externa, Brasília, 2011, Dissertação (mestrado) - Faculdade de Tecnologia, Universidade de Brasília, 149p.

[05] ALBUQUERQUE, N. G. B. Comportamento das ligações de lajes lisas de concreto armado com pilares de borda sujeitas a excentricidades interna e externas, Brasília, 2014, Tese (doutorado) - Faculdade de Tecnologia, Universidade de Brasília, 204p.

[06] ASSOCIAÇÃO BRASILEIRA DE NORMAS TÉCNICAS. Concreto - Ensaio de compressão de corpos-de-prova cilíndricos - Métodos de ensaio - NBR 5739, Rio de Janeiro, 1994.

[07] ASSOCIAÇÃO BRASILEIRA DE NORMAS TÉCNICAS. Argamassas e concreto - Determinação da resistência à tração por compressão diametral de corpos-de-prova cilíndricos - Método de ensaio - NBR 7222, Rio de Janeiro, 1994.

[08] ASSOCIAÇÃO BRASILEIRA DE NORMAS TÉCNICAS. Concreto - Determinação do módulo de deformação elástica e diagrama tensão deformação - Método de ensaio - NBR 8522, Rio de Janeiro, 1994.

[09] Catman® 4.5 Operating Manual. HBM Software. Hottinger Balswin Messtechnik GmbH. Darmstadt, Germany. 2003. 